\section{Drip-applied Soil Fumigation for Freesia Production}

\author{
James S. Gerik
}

ADDITIONAL INDEX WORDs. methyl bromide, 1,3-dichloropropene, chloropicrin, iodomethane, furfural, cut flower

SumMARY. Field trials were conducted to test fumigants as alternatives to methyl bromide (MB) for production of hybrid freesia (Freesia $\times$ bybrida). One trial compared rates of 1,3-dichloropropene (DP) combined with chloropicrin (CP); the second trial compared iodomethane (IM) together with CP, DP:CP, and furfural with and without metham sodium; and the third trial compared rates and formulations of IM:CP to the standard MB:CP treatments. Most treatments reduced populations of Pythium spp. and controlled weeds compared to the untreated controls. Formulations of IM:CP reduced the incidence of disease caused by Fusarium oxysporum. Treatments of IM:CP performed as well as MB:CP, and treatments of DP:CP performed as well as IM:CP. Presently only the DP, CP and metham sodium formulations are registered for use on ornamental crops. Registration of the IM formulations will improve the options available to cut flower growers for management of plant pathogens and weeds.

$\mathrm{I}$ n 2003, California growers produced cut flowers and cut cultivated ornamental greens with a wholesale value of more than $\$ 330$ million (U.S. Department of Agriculture, 2004). Crops were produced on 2817 acres of covered area and on 9689 acres of open ground. The three topvalued cut flower categories are lilies (Lilum spp.), roses (Rosa spp.), and tulips (Tulipa spp.), with hundreds of other cut flower crops also produced in California.

Hybrid freesia is grown for cut flower production in field soil under shade on the coast of California. A variety of weed species can quickly overgrow the sparse canopy of the crop, reducing yield and quality. The crop is susceptible to Fusarium oxysporum, which causes fusarium yellows (Farr et al., 1989). Preplant soil fumigation with methyl bromide/chloropicrin (MB:CP) is commonly employed as a means of weed and pathogen control. The soils are usually fumigated with a 98 MB:2 CP formulation using the hot gas method (the chemical is condensed in a heat exchanger and injected directly under a polyethylene tarp), or the fumigants may be shank-injected using

San Joaquin Valley Agricultural Sciences Center, USDAARS, 9611 S. Riverbend Ave., Parlier, CA 93648.

Acknowledgments. The author thanks Ernie Leyva and Patricia Martinez for technical assistance. Thanks to All Seasons Flowers and Dramm \& Echter for hosting the trials. This research was supported in part by grants from the California Cut Flower Commission. either a $67 \mathrm{MB}: 33 \mathrm{CP}$ or $50 \mathrm{MB}: 50$ CP formulation.

The broad-spectrum biological activity of MB:CP makes the product a key tool for the control of pathogens and weeds for freesia production as well as many other cut flower crops. The growers require a tool such as $\mathrm{MB}$ : CP to ensure a successful crop and to avoid great financial losses that would result from crop failure (Deepak et al., 1996). Chemical companies have been reluctant to register products for ornamental crops because of the relatively few acres involved and the high risk due to the value of these crops. Many of the cut flower crops have a relatively short growing period, and often a grower will follow one crop niche market. This practice limits the availability of products that might be used due to residual chemical effects and the extreme sensitivity of certain with a different species to supply a cut flower crops. In 1988, the U.S. signed the Montreal Protocol, which prohibits the production and importation of MB after l Jan. 2005 (U.S. Environmental Protection Agency, 1993). Some use will continue in the short term for quarantine and pre-shipment uses as well as for approved critical uses. Cut flower growers may currently use methyl bromide under the critical use exemption, but this could change on a yearly basis. Alternatives must be found for the very near future.

Since the widespread introduction and use of MB:CP, methods have been improved to deliver alternative fumigants through drip irrigation systems (Ajwa et al., 2002; Apt and Caswell, 1988; Roberts et al., 1988). This technology allows for better distribution of these chemicals, which have lower vapor pressure compared to $\mathrm{MB}$, and the fumigants are applied through a totally enclosed system, increasing worker safety as well as environmental impact.

Potential methyl bromide alternatives include formulations containing 1,3-dichloropropene (DP) and CP (Ajwa and Trout, 2004; Chellami et al., 1997; Csinos et al., 2000, 2002; Fennimore et al., 2003; Gilreath et al., 2004a, 2004b, 2004c; Hutchinson et al., 2004; Larson and Shaw, 2000; Nelson et al., 2001; Rieger et al., 2001; Webster et al., 2001). An emulsified concentrate containing 60.8\% DP and 33.3\% CP (InLine; Dow AgroSciences, Indianapolis) may be applied through drip irrigation systems (Ajwa et al., 2002). The commercial product is currently labeled at rates from 13 to $56 \mathrm{gal} /$ acre, the maximum rate for pineapple (Ananas sellowiawa). Presently, the maximum rate that can be used on ornamentals is $20.5 \mathrm{gal} / \mathrm{acre}$. Previous studies with strawberry (Fragaria $\times$ ananassa) have

\begin{tabular}{llll}
\hline $\begin{array}{l}\text { Units } \\
\text { To convert U.S. to SI, } \\
\text { multiply by }\end{array}$ & U.S. unit & SI unit & $\begin{array}{l}\text { To convert SI to U.S., } \\
\text { multiply by }\end{array}$ \\
\hline 0.4047 & $\mathrm{acre}(\mathrm{s})$ & $\mathrm{ha}$ & 2.4711 \\
29.5735 & $\mathrm{fl} \mathrm{oz}$ & $\mathrm{mL}$ & 0.0338 \\
0.3048 & $\mathrm{ft}$ & $\mathrm{m}$ & 3.2808 \\
0.0929 & $\mathrm{ft}^{2}$ & $\mathrm{~m}^{2}$ & 10.7639 \\
3.7854 & $\mathrm{gal}$ & $\mathrm{L}$ & 0.2642 \\
9.3540 & $\mathrm{gal} / \mathrm{acre}$ & $\mathrm{L} \cdot \mathrm{ha}^{-1}$ & 0.1069 \\
2.5400 & inch(es) & $\mathrm{cm}$ & 0.3937 \\
1.1209 & $\mathrm{lb} / \mathrm{acre}$ & $\mathrm{kg} \cdot \mathrm{ha}^{-1}$ & 0.8922 \\
0.0254 & $\mathrm{mil}$ & $\mathrm{mm}$ & 39.3701 \\
28.3495 & $\mathrm{oz}$ & $\mathrm{g}$ & 0.0353 \\
6.8948 & $\mathrm{psi}$ & $\mathrm{kPa}$ & 0.1450 \\
& & &
\end{tabular}


shown that higher rates ( $42 \mathrm{gal} / \mathrm{acre}$ ) control disease and weeds as well as $\mathrm{MB}: \mathrm{CP}$ fumigation, and that yield was as good as the standard MB:CP treatment (Ajwa and Trout, 2004). Another material proposed as an alternative to $\mathrm{MB}: \mathrm{CP}$ soil fumigation is furfural [2furaldehyde (Multiguard Protect; Agriguard, Cranford, N.J.) (Bauske et al., 1994, 1997; Rodriguez-Kabana et al., 1993)], both alone and in combination with a methyl isothiocyanate generator such as metham sodium [MS (Vapam HL;AMVAC Chemical, Los Angeles)]. Several different formulations and rates of IM and CP (Midas; Arvesta, San Francisco) have been tested as alternatives in strawberry as well as other crops (Ajwa and Trout, 2004; Becker et al., 1998; Dowler, 1999; Duniway, 2002; Eayre et al., 2000; Fennimore et al., 2003; Hutchinson et al., 1999a, 1999b, 2000, 2004; McMillan et al., 1996; Ohr et al., 1996; Webster et al., 2001). Neither furfural nor IM are presently labeled for use in the U.S. on any crop.

During 2003 and 2004, three experiments were established to evaluate alternative fumigants applied through the drip irrigation systems for freesia production in California. This research is crucial not only to provide economical alternatives for cut flower production, but also is required to secure critical use exemptions to continue using $\mathrm{MB}$ in areas where drip fumigation cannot be used.

\section{Materials and methods}

\section{Trial 1: Nipomo}

A freesia flower trial, to compare rates of DP:CP, was established in Nipomo, Calif. (San Luis Obispo County) on Oceano sand (9\% to 30\% slope; sand: $92 \%$, silt: $5 \%$, clay: $3 \%$; organic matter: $1.4 \%)$. The trial was conducted under shadecloth (netted, generic shade, $50 \%$ light exclusion). A $6 \times 6$ Latin square design was used because the grower plants different cultivars of the crop in each bed. The plots were 180 inches long and 42 inches wide. The treatments were delivered in five irrigation tapes evenly spaced over the width of the bed. The drip tape was a T-Tape model 506-04-1.0 (T-Systems International, San Diego) with emitter spacing of 4 inches and flow rate of 1 $\mathrm{gal} / \mathrm{min}$ per $100 \mathrm{ft}$ at $8 \mathrm{psi}$. The plots were covered with polyethylene mulch ( 3 mil thick) before treatments were applied. The treatments were applied 1 Oct. 2003 in 66 gal of water per plot. The trial consisted of five DP:CP rates $(20,30,40,50$, and $56 \mathrm{gal} /$ acre $)$ compared to the water control. The polyethylene mulch was removed 2 weeks following the applications and five soil cores ( 1 -inch diameter) were collected from the surface 6 inches of each plot. The soil samples were pooled and returned to the laboratory where they were allowed to dry at room temperature for at least 2 weeks. Populations of Pythium spp. were determined from the samples by dilution plating ( $1 \mathrm{~g}$ soil in $10 \mathrm{~mL}$ sterile water; 0.5 $\mathrm{mL}$ on each of five replicated plates) on Martin's medium (Martin, 1992); populations of Fusarium oxysporum were determined by dilution plating ( 1 g soil in $10 \mathrm{~mL}$ sterile water; $0.3 \mathrm{~mL}$ on each of five replicated plates) on Komada's medium (Komada, 1975). The trial was planted with corms on 24 Nov. 2003. Weeds were counted in the center of each plot $\left(1-\mathrm{m}^{2}\right.$ area $)$ on 2 Dec. 2003 and again on 7 Jan. 2004. Final data for this trial were collected on 6 Apr. 2004. Measurements on this date included plant height (average of five plants in center $\mathrm{l} \mathrm{m}^{2}$ ), a vigor rating, and disease incidence. All data were analyzed by PROC GLM of SAS (SAS Institute, Cary, N.C.) and means were separated by Fisher's protected least significant difference.

\section{Trial 2: Encinitas}

The second freesia trial was established in Encinitas, Calif. (San Diego County) on Marina loamy coarse sand (2\% to $9 \%$ slope; sand: $80 \%$, silt $10 \%$, clay $10 \%$; o.m. $4.8 \%$ ) to test both furfural alone and in combination with MS, the DP:CP formulation used in the first trial and an IM:CP formulation. The trial was conducted in a greenhouse and the experimental design was a $5 \times 5$ Latin square. The plots were 240 inches long and 46 inches wide. The treatments were delivered in four irrigation tapes evenly spaced over the width of the bed. The tape was Toro model EA5080867-750 (The Toro Co. El Cajon, Calif.) with emitter spacing of 8 inches and flow rate of $0.67 \mathrm{gal} / \mathrm{min}$ per $100 \mathrm{ft}$ at 10 psi. Each bed was covered with high density polyethylene sheeting before chemigation. The treatments, made on 15 Oct. 2004 in 72 gal of water per plot, included 1) IM:CP (50:50) at $400 \mathrm{lb} /$ acre; 2) DP:CP at 56 gal/acre;
3) furfural at $960 \mathrm{lb} / \mathrm{acre}$;) furfural at $480 \mathrm{lb} /$ acre + metham sodium at $210 \mathrm{lb} /$ acre; and 5) a non-treated control. All chemicals were emulsified by the formulators except for metham sodium, which is water soluble. The trial was planted with corms on 5 Nov. 2003. Soil samples were collected and processed as in the previous trial. On 5 Nov. 2003, weed counts were made on the entire plots. Final data were collected on 24 Feb. 2004 and the same parameters were measured as in the previous trial.

\section{Trial 3: Nipomo}

The final freesia trial was established on the same ranch as Trial 1 in Nipomo to compare rates and formulations of IM:CP to an untreated control and to a standard MB:CP treatment. The soil characteristics, growing methods, and irrigation equipment, and experimental design were the same as in trial one. Treatments were made on 26 May 2004 and included l) IM:CP (50:50) at $300 \mathrm{lb} / \mathrm{acre} ; 2)$ IM:CP (50:50) at $400 \mathrm{lb} /$ acre; 3$) \mathrm{IM}$ : $\mathrm{CP}(33: 67)$ at $300 \mathrm{lb} / \mathrm{acre}$; 4$) \mathrm{IM}: \mathrm{CP}$ (33:67) at $400 \mathrm{lb} /$ acre; 5) $\mathrm{MB}: \mathrm{CP}$ $(50: 50)$ at $400 \mathrm{lb} / \mathrm{acre}$; and 6$)$ water (control). The treatments were made through the drip irrigation tape in 66 gal of water per plot. The trial was planted with corms on 6 July 2004 . Soil samples were collected and processed as before. Weeds were counted in the center of each plot ( $1-\mathrm{m}^{2}$ area $)$ on 12 July and 11 Aug. 2004. Final data were collected on 17 Nov. 2004 and the same parameters were measured as before; the numbers of flower spikes were also counted in each plot.

\section{Results and discussion}

In the first Nipomo trial, Pythium spp. populations were greatly reduced in all treatments compared to the control plots (Table 1). Fusarium oxysporum populations averaged $1210 \mathrm{cfu} / \mathrm{g}$ soil in the control plots and could not be determined for any of the chemical treatments due to interference by a Trichoderma species, which probably occurred due to the biological vacuum created by the chemical treatment that was exploited by the Trichoderma (Ohr et al., 1973). Early season weed control was reasonably good with all treatments compared to the control plots (Table 1). The most prevalent weed, mustard (Brassica sp.), still had lower populations during the second count 
Table 1. Populations of Pythium spp. in soil samples, weed counts, stem length, vigor rating, and counts of plants symptomatic of fusarium yellows in a freesia trial treated with several rates of 1,3 -dichloropropene $(60.8 \%)+$ chloropicrin $(33.3 \%)$ in Nipomo, Calif., in Oct. 2003 (values are the average of six plots). Plant height, vigor, disease, and weed cover data collected on 16 Apr. 2004.

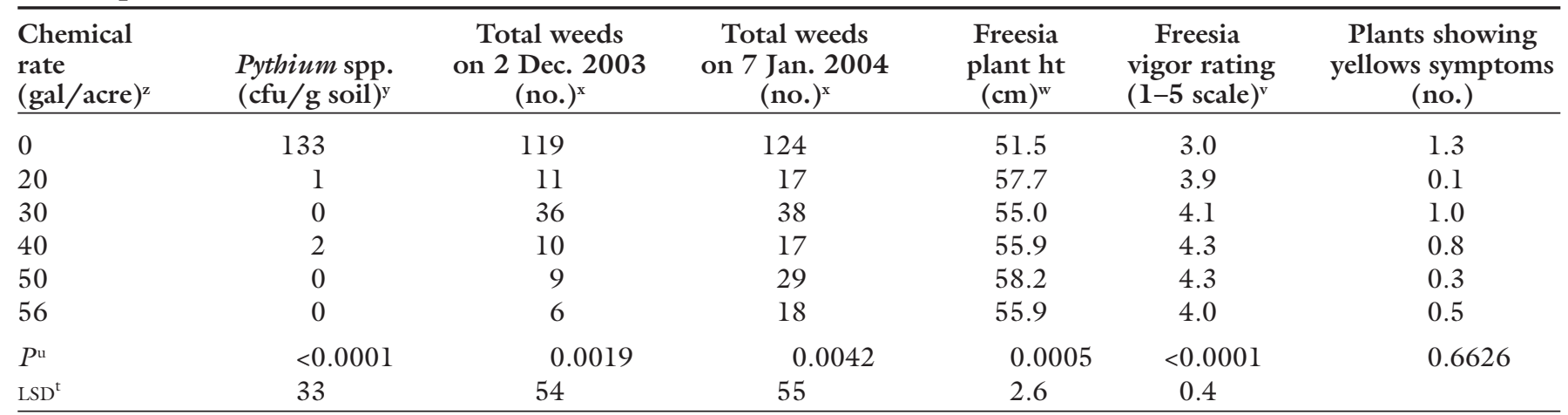

${ }^{2} 1 \mathrm{gal} / \mathrm{acre}=9.3540 \mathrm{~L} \cdot \mathrm{ha}^{-1}$

$\mathrm{l} 1 \mathrm{cfu} / \mathrm{g}=0.0353 \mathrm{cfu} / \mathrm{oz}$.

xAll weed counts were taken from the center $1 \mathrm{~m}^{2}\left(10.8 \mathrm{ft}^{2}\right)$ of each plot.

w $\mathrm{cm}=0.3937$ inch

"Vigor was rated subjectively from a low value of 1 to a high of 5 based on the appearance of the entire plot

urobability from the analysis of variance.

tLeast significant difference.

Table 2. Populations of Pythium spp. and Fusarium oxysporum in soil samples, weed counts plant height, and counts of fusarium yellows in a freesia trial treated by drip irrigation with various chemical combinations in Encinitas, Calif., in Oct. 2003 (values are the average of five plots). Plant height, and disease data collected on 24 Feb. 2004.

\begin{tabular}{|c|c|c|c|c|c|c|}
\hline$\underline{\text { Treatment }}^{\mathrm{z}}$ & $\begin{array}{l}\text { Pythium spp. } \\
\text { (cfu/g soil) }\end{array}$ & $\begin{array}{l}\text { F. oxysporum } \\
\text { (cfu/g soil) }\end{array}$ & $\begin{array}{c}\text { Bitter-cress } \\
(\text { no. })^{x}\end{array}$ & $\begin{array}{c}\text { Chickweed } \\
(\text { no. })^{\mathrm{x}}\end{array}$ & $\begin{array}{c}\text { Freesia } \\
\text { plant ht } \\
(\mathrm{cm})^{\mathrm{w}}\end{array}$ & $\begin{array}{c}\text { Plants showing } \\
\text { yellows symptoms } \\
\text { (no.) }\end{array}$ \\
\hline IM:CP & 1 & 262 & 0 & 0 & 91.4 & 25 \\
\hline DP:CP & 6 & 1040 & 1 & 0 & 89.9 & 12 \\
\hline Furfural & 97 & 643 & 8 & 3 & 87.0 & 26 \\
\hline FMS & 27 & 1096 & 0 & 1 & 90.4 & 18 \\
\hline Control & 171 & 1507 & 30 & 8 & 87.1 & 30 \\
\hline$P^{\mathrm{v}}$ & 0.0001 & 0.1221 & 0.0003 & 0.0005 & 0.0120 & 0.3610 \\
\hline $\mathrm{LSD}^{\mathrm{u}}$ & 58 & & 11 & 3 & 2.7 & \\
\hline
\end{tabular}

${ }^{2}$ Treatments included (IM:CP) iodomethane + chloropicrin (50:50) at $400 \mathrm{lb} / \mathrm{acre},(\mathrm{DP}: \mathrm{CP}) \mathrm{1}, 3$-dichloropropene + chloropicrin at 56 gal/acre, furfural at $960 \mathrm{lb} /$ acre, (FMS ) furfural at $480 \mathrm{lb} / \mathrm{acre}+$ metham sodium $210 \mathrm{lb} / \mathrm{acre},($ control $)$ water $\left(1.0 \mathrm{lb} / \mathrm{acre}=1.1209 \mathrm{~kg} \cdot \mathrm{ha} \mathrm{a}^{-1} ; \mathrm{l} \mathrm{gal} / \mathrm{acre}=9.3540 \mathrm{~L} \cdot \mathrm{ha} \mathrm{a}^{-1}\right)$. y $1 \mathrm{cfu} / \mathrm{g}=0.0353 \mathrm{cfu} / \mathrm{oz}$.

${ }^{\mathrm{x}}$ All weed counts were taken from entire plot.

${ }^{\mathrm{w}} \mathrm{l} \mathrm{cm}=0.3937$ inch.

vProbability obtained from the analysis of variance (ANOVA)

uLeast significant difference. Differences among means according to the LSD value are invalid unless protected by the $P$ obtained from the ANOVA $(P \leq$ $0.05)$.

for all other treatments compared to the control, but the differences were nonsignificant (data not shown); total numbers of weeds were also lower at this date for all treatments (Table 1 ). At the end of the trial, all treatments had taller stems, better vigor, and less weed cover compared to the control (Table 1). The incidence of fusarium yellows was not significantly different for any treatments, but the incidence was very low throughout the trial (Table 1).

For the Encinitas trial, average populations of Pythium spp. were lower for all treatments compared to the control, and the IM:CP, DP: $\mathrm{CP}$, and furfural plus metham sodium treatments had lower Pythium spp. counts compared to the treatment with furfural alone (Table 2). Populations of $F$. oxysporum were not significantly different among treatments (Table 2). On 5 Nov. the two most prevalent weeds were chickweed (Cerastium arvense) and bitter-cress (Barbarea vulgaris). Average weed counts were lower in all treatments compared to the control (Table 2). At the end of the trial, average plant height was greater for all treatments except for furfural alone compared to the control (Table 2 ). There was no significant difference in the incidence of fusarium yellows among any of the treatments (Table $2)$. Vigor ratings were not significantly different between treatments (data not shown).

For the second Nipomo trial, populations of Pythium spp. were reduced for all chemical treatments compared to the control (Table 3). Populations of F. oxysporum averaged $1963 \mathrm{cfu}$ for the control plots and again could not be determined for any of the chemical treatments, due to the same reason as in the first Nipomo trial. All chemical treatments had lower weed counts compared to the control on both dates (Table 3 ). At the end of the trial, all chemical treatments had higher vigor ratings and less fusarium yellows disease incidence compared to the control. There was no significant 
Table 3. Populations of Pythium spp. in soil samples, weed counts, vigor rating, counts of plants symptomatic of fusarium yellows, and number of flower spikes in a freesia trial treated with several formulations of fumigants in Nipomo, Calif., in May 2004 (values are the average of six plots). Vigor, disease, and flower spike data collected on 17 Nov. 2004.

\begin{tabular}{|c|c|c|c|c|c|c|}
\hline Treatment $^{z}$ & $\begin{array}{l}\text { P. ultimum } \\
(\mathrm{cfu} / \mathrm{g} \text { soil })^{\mathrm{y}}\end{array}$ & $\begin{array}{c}\text { Total weeds } \\
\text { on } 12 \text { July } 2004 \\
(\text { no. })^{x}\end{array}$ & $\begin{array}{c}\text { Total weed } \\
\text { count on } \\
11 \text { Aug. } 2004\end{array}$ & $\begin{array}{c}\text { Freesia } \\
\text { vigor rating } \\
(1-5 \text { scale })^{\mathrm{w}} \\
\end{array}$ & $\begin{array}{c}\text { Plants showing } \\
\text { yellows symptoms } \\
\text { (no.) }\end{array}$ & $\begin{array}{c}\text { Flower } \\
\text { spikes } \\
\text { (no.) }\end{array}$ \\
\hline IM:CP (50:50) $400 \mathrm{lb} /$ acre & 55 & 12 & 77 & 3.5 & 21 & 35 \\
\hline IM:CP (33:67) $300 \mathrm{lb} /$ acre & 55 & 7 & 94 & 3.3 & 18 & 38 \\
\hline IM:CP (33:67) $400 \mathrm{lb} /$ acre & 2 & 7 & 62 & 3.3 & 20 & 24 \\
\hline$P^{\mathrm{v}}$ & 0.0008 & 0.0020 & 0.0018 & 0.0004 & $<0.0001$ & 0.0623 \\
\hline $\mathrm{LSD}^{\mathrm{u}}$ & 67 & 10 & 99 & 0.9 & 7 & \\
\hline
\end{tabular}

Treatments included: 1) iodomethane (IM) + chloropicrin (CP) (50:50) at $300 \mathrm{lb} / \mathrm{acre} ; 2) \mathrm{IM}: \mathrm{CP}(50: 50)$ at $400 \mathrm{lb} / \mathrm{acre} ; 3) \mathrm{IM}: \mathrm{CP}(33: 67)$ at $300 \mathrm{lb} / \mathrm{acre} ; 4) \mathrm{IM}: \mathrm{CP}$ $(33: 67)$ at $400 \mathrm{lb} / \mathrm{acre} ; 5)$ methyl bromide $+\mathrm{CP}(\mathrm{MB}: \mathrm{CP})(50: 50)$ at $400 \mathrm{lb} / \mathrm{acre}$, and 6$)$ water $(\mathrm{control})\left(1.0 \mathrm{lb} / \mathrm{acre}=1.1209 \mathrm{~kg} \cdot \mathrm{ha}{ }^{-1}\right)$.

y $1 \mathrm{cfu} / \mathrm{g}=0.0353 \mathrm{cfu} / \mathrm{oz}$

Aall weed counts were taken from the center $1 \mathrm{~m}^{2}\left(10.8 \mathrm{ft}^{2}\right)$ of each plot.

wigor was rated from a low value of 1 to a high of 5 based on the appearance of the entire plot.

"Probability obtained from the analysis of variance (ANOVA).

"Least significant difference. Differences among means according to the LSD value are invalid unless protected by the $P$ obtained from the ANOVA procedure $(P \leq 0.05)$

difference between treatments in the number of flower spikes produced (Table 3). There was no difference in plant height among treatments (data not shown).

Most of the treatments in these trials did a good job reducing the populations of Pythium spp. compared to the water-only controls. In the Encinitas trial, populations of Pythium spp. were reduced more effectively than populations of $F$. oxysporum, which has been previously reported (Hutchinson et al., 2000). Incidence of fusarium yellows was low in the first two trials, probably because they were conducted in the winter when disease incidence is rare. However, incidence of fusarium yellows was reduced by MI:CP in the trial with the greatest incidence of disease.

Weed control was good with all the treatments compared to untreated controls and were comparable to the MB:CP standard treatment in the final trial. Furfural alone did not perform as well as the other treatments and may not be adequate as a stand-alone treatment for this use.

In conclusion, the data indicate that a successful freesia crop can be produced using combinations of alternative chemicals applied through drip irrigation systems. Presently, only CP, DP:CP, and metham sodium formulations are registered for use on ornamental crops. Registration of the IM:CP formulations will improve the options of freesia growers to manage disease and weeds in their crops.

\section{Literature cited}

Ajwa, H.A. and T. Trout. 2004. Drip application of alternative fumigants to methyl bromide for strawberry production. HortScience 39:1707-1715.

Ajwa, H.A., T. Trout, J. Mueller, S. Wilhelm, S.D. Nelson, R. Soppe, and D. Shatley. 2002. Application of alternative fumigants through drip irrigation systems. Phytopathology 92:1349-1355.

Apt, W.J. and E.P. Caswell. 1988. Application of nematicides via drip irrigation. Ann. Appl. Nematol. 2:1-10.

Bauske, E.M., P.A. Backman, K.M. Harper, P.M. Brannen, R. Rodriguez-Kabana, and J.W. Kloepper. 1997. Effect of botanical aromatic compounds and seed-surface $\mathrm{pH}$ on growth and colonization of cotton plant growth-promoting rhizobacteria. Biocontrol Sci. Technol. 7:415-421.

Bauske, E.M., R. Rodriguez-Kabana, V. Estaun, J.W. Kloepper, D.G. Robertson, C.F. Weaver, and P.S. King. 1994. Management of Meloidogyne incognita on cotton by use of botanical aromatic compounds. Nematropica 24:143-150.

Becker, J.O., H.D. Ohr, N.M. Grech, M.E. McGiffen, Jr., and J.J. Sims. 1998. Evaluation of methyl iodide as a soil fumigant in container and small field plot studies. Pest. Sci. 52:58-62.

Chellami, D.O., S.M. Olson, D.J. Mitchell, I. Secker, and R. McSorley. 1997. Adaptation of soil solarization to the integrated management of soilborne pests of tomato under humid conditions. Phytopathology $87: 250-258$.
Csinos, A.S., D.R. Sumner, W.C. Johnson, A.W. Johnson, R.M. McPherson, and C.C. Dowler. 2000. Methyl bromide alternatives in tobacco, tomato and pepper transplant production. Crop Protection 19:39-49.

Csinos, A.S., T.M. Webster, D.R. Sumner, A.W. Johnson, C.C. Dowler, and K.W. Seebold. 2002. Application and crop safety parameters for soil fumigants. Crop Protection 21:973-982.

Deepak, M.S., T.H. Spreen, and J.J. VanSickle. 1996. An analysis of the impact of a ban of methyl bromide on the U.S. winter fresh vegetable market. J. Agr. Appl. Econ. 28:433-443.

Dowler, C.C. 1999. Herbicide activity of metham, methyl iodide, and methyl bromide applied through irrigation systems. Proc. Southern Weed Sci. Soc. 52:77-78

Duniway, J.M. 2002. Status of chemical alternatives to methyl bromide for preplant fumigation of soil. Phytopathology 92:1337-1343.

Eayre, C.G., J.J. Sims, H.D. Ohr, and B. Mackey. 2000. Evaluation of methyl iodide for control of peach replant disorder. Plant Dis. 84:1177-1179.

Farr, D.F., G.F. Bills, G.P. Chamuris, and A.Y. Rossman. 1989. Fungi on plants and plant products in the United States. Amer. Phytopathol. Soc., St. Paul, Minn.

Fennimore, S.A., M.J. Haar, and H.A. Ajwa. 2003. Weed control in strawberry provided by shank- and drip-applied methyl bromide alternative fumigants. HortScience 38:55-61. 
Gilreath, J.P., J.P. Jones, B.M. Santos, and A.J. Overman. 2004a. Soil fumigant evaluations for soilborne pest and Cyperus rotundus control in fresh market tomato. Crop Protection 23:889-893.

Gilreath, J.P., J.W. Noling, and B.M. Santos. 2004b. Methyl bromide alternatives for bell pepper (Capsicum annuum) and cucumber (Cucumis sativus) rotations. Crop Protection 23:347-351.

Gilreath, J.P., B.M. Santos, P.R. Gilreath, J.P. Jones, and J.W. Noling. 2004c. Efficacy of 1,3-dichloropropene plus chloropicrin application methods in combination with pebulate and napropamide in tomato. Crop Protection 23:1187-1191.

Hutchinson, C.M., M.E. McGiffen, Jr., H.D. Ohr, J.J. Sims, and J.O. Becker. 1999a. Evaluation of methyl iodide as a soil fumigant for root-knot nematode control in carrot production. Plant Dis. $83: 33-36$.

Hutchinson, C.M., M.E. McGiffen, Jr., J.J. Sims, and J.O. Becker. 2004. Fumigant combinations for Cyperus esculentum $\mathrm{L}$ control. Pest Mgt. Sci. 60:369-374.

Hutchinson, C.M., M.E. McGiffen, H.D. Ohr, J.J. Sims, and J.O. Becker. 1999b. Efficacy of methyl iodide soil fumigation for control of Meloidogyne incognita, Tylenchulus semipenetrans and Heterodera schachtii. Nematology 1:407-414.

Hutchinson, C.M., M.E. McGiffen, H.D. Ohr, J.J. Sims, and J.O. Becker. 2000. Efficacy of methyl iodide and synergy with chloropicrin for control of fungi. Pest Mgt. Sci. 56:413-418.
Komada, H. 1975. Development of a selective medium for quantitative isolation of Fusarium oxysporum from natural soil. Rev. Plant Protection Res. 8:114-125.

Larson, K.D. and D.V. Shaw. 2000. Soil fumigation and runner plant production: A synthesis of four years of strawberry nursery field trials. HortScience 35:642-646.

Martin, F.N. 1992. The genus Pythium, p. 39-49. In: L.L. Singleton, J.D. Mihail, and C.M. Rush (eds.). Methods for research on soilborne phytopathogenic fungi. Amer. Phytopathol. Soc., St. Paul, Minn.

McMillan, R.T., Jr., H.H. Bryan, H.D. Ohr, and J.J. Sims. 1996. Methyl iodide a replacement of methyl bromide as a soil fumigant for tomatoes. Proc. Fla. State Hort. Soc. 109:200-201.

Nelson, S.D., C. Riegel, L.H. Allen, Jr., D.W. Dickson, J. Gan, S.J. Locascio, and D.J. Mitchell. 2001. Volatilization of 1,3dichloropropene in Florida plasticulture and effects on fall squash production. J. Amer. Soc. Hort. Sci. 126:496-502.

Ohr, H.D., D.E. Munnecke, and J.L. Bricker. 1973. The interaction of Armillaria mellea and Trichoderma spp. as modified by methyl bromide. Phytopathology 63:965-973.

Ohr, H.D., J.J. Sims, N.M. Grech, J.O. Becker, and M.E. McGiffen, Jr. 1996. Methyl iodide, an ozone-safe alternative to methyl bromide as a soil fumigant. Plant Dis. 80:731-735.
Rieger, M., G. Krewer, and P. Lewis. 2001. Solarization and chemical alternatives to methyl bromide for preplant soil treatment of strawberries. HortTechnology $11: 258-264$.

Roberts, P.A., A.C. Magyarosy, W.C. Matthews, and D.M. May.1988.Effects of metam-sodium applied by drip irrigation on root-knot nematodes Pythium ultimum and Fusarium species in soil and on carrot and tomato roots. Plant Dis. 72:213-217.

Rodriguez-Kabana, R., J.W. Kloepper, C.F. Weaver, and D.G. Robertson. 1993. Control of plant parasitic nematodes with furfural-A naturally occurring fumigant. Nematropica 23:63-73.

U.S. Department of Agriculture. 2004. Floriculture crops 2003 summary. Natl. Agr. Stat. Serv. 24 Jan. 2005. <http:// usda.mannlib.cornell.edu/reports/nassr/ other/zfc-bb/florano4.pdf>.

U.S. Enviromental Protection Agency. 1993. Protection of stratospheric ozone. U.S. Environ. Protection Agency, Washington, D.C. Fed Reg. 58:15014-15049.

Webster, T.M., A.S. Csinos, A.W. Johnson, C.C. Dowler, D.R. Sumner, and R.L. Fery. 2001. Methyl bromide alternatives in a bell pepper-squash rotation. Crop Protection 20:605-614. 